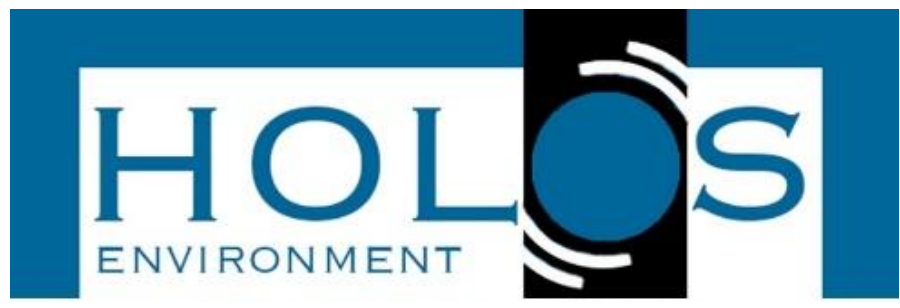

\title{
PATENTEABILIDADE DOS ORGANISMOS GENETICAMENTE MODIFICADOS (OGMs)
}

\section{GENETICALLY MODIFIED ORGANISM'S PATENTABILITY}

\author{
Melina Scarassati Galvani ${ }^{1}$
}

Artigo recebido em: 05/11/2018 e aceito para publicação em: 14/06/2019.

DOI: http://dx.doi.org/10.14295/holos.v19i2.12321

Resumo: $O$ presente artigo tem o escopo de fazer um breve estudo sobre um aspecto peculiar da biotecnologia, qual seja, os organismos geneticamente modificados, e a questão da patenteabilidade que norteia o tema. Nessa órbita, este artigo inicia sua análise, com exposição sucinta à temática dos organismos geneticamente modificados (OGMs), explicitando a diferença entre o termo genérico OGM e o termo "transgênico", mais específico. Por conseguinte, aborda-se a legislação concernente (internacional e nacional), bem como os casos concretos que versam sobre o assunto. Ainda nessa órbita, o presente estudo traz à baila a questão da rotulagem, discussão essa de notória atualidade. Em outra parte, o trabalho aborda o aspecto da propriedade industrial, propriamente acerca do patenteamento dos OGMs. Com o intuito, pois, de encaminhar para uma conclusão do mote alavancado, o artigo enfrenta, de modo conciso, o posicionamento do tema na atual conjuntura brasileira.

Palavras-chave: Biotecnologia. Biossegurança. Organismos geneticamente modificados (OGMs).

Abstract: This article has the scope to briefly study a peculiar aspect of biotechnology, namely genetically modified organisms, and the issue of patentability that guides the theme. In this orbit, this article begins its analysis with a succinct exposition related to genetically modified organisms (GMOs), explaining the difference between the generic term - GMO and the more specific one - "transgenic". Therefore, the relevant legislation (international and national) is discussed, as well as the legal cases associated with the subject. Still in this orbit, the present study brings up the question of labeling, an extremely current discussion. In another fragment, the paper addresses the industrial property subject specifically concerning about the patenting of GMOs. Moving towards a conclusion of the present exposition, the article confronts in a concise way, the current aspect of the theme in the Brazilian system.

Keywords: Biotechnology. Biosafety. Genetically modified organisms (GMOs).

\section{UMA VISÃO GERAL ACERCA DOS OGMs}

\subsection{Biotecnologia, engenharia genética, OGM, biodiversidade e biossegurança: uma visão acerca dos novos termos da ciência}

O termo Biotecnologia ganhou destaque, em 1953, quando dois cientistas da

\footnotetext{
1 Universidade Metodista de Piracicaba (Unimep), Piracicaba, SP. E-mail: (melinagalvani@gmail.com)
} 
Universidade de Cambridge, James Watson e Francis Crick, desentranharam a estrutura molecular do $A D N^{2}$. Um dos descobrimentos mais importantes do século $X X$, haja vista que o ADN é a molécula que contém a informação genética que determina todas as características de um organismo.

A exploração comercial da "biotecnologia" começou na década de 1970, quando os cientistas passaram a transferir genes de uma espécie à outra. Essa tecnologia moderna, desenvolvida, mais precisamente, em 1973, permitia a transferência do material genético de um organismo para outro, possibilitando a identificação e inserção, no genoma de um determinado organismo, de um único gene responsável pela característica de interesse (ao invés de transferi-lo por meio de cruzamentos reprodução sexual, onde todo o conjunto de genes dos dois organismos mistura-se em combinações aleatórias, limitando a variação natural dentro do genoma ${ }^{3}$ de cada espécie).

Desse modo, consiste a "biotecnologia" no conjunto de técnicas que permitem isolar células de organismos vivos (ou algumas de suas partes), com a finalidade de obter bens e serviços que satisfaçam as mais diversas necessidades humanas. Ou, como melhor definiu a Convenção da Biodiversidade ${ }^{4}$, "biotecnologia significa qualquer aptidão tecnológica que utilize sistemas biológicos, organismos vivos, ou seus derivados, para fabricar ou modificar produtos ou processos para utilização específica"5.

Assim, quando essas técnicas são empregadas no sentido de modificar o genoma de um determinado organismo, elas passam a constituir um setor da Biotecnologia denominado Engenharia Genética, definida pela Lei 8974/1995 como "atividade de manipulação de moléculas ADN/ARN recombinante" ${ }^{6}$.

Esses conceitos têm definido e delimitado o que se denomina Biotecnologia moderna. $\mathrm{O}$ uso da biotecnologia moderna, também conhecida como tecnologia do ADN recombinante, implica no conhecimento e isolamento de sequências de ADN

\footnotetext{
${ }^{2} \mathrm{ADN}$ = ácido desoxirribonucléico, mais conhecido pela abreviação inglesa DNA (deoxyribonucleic acid). É uma molécula em forma de dupla hélice, composta por pares de bases nitrogenadas (adenina, timina, citosina e guanina), capaz de armazenar todas as informações necessárias para caracterizar um ser vivo.

3 É o conjunto de todo o material genético de um organismo, ou seja, "toda a informação hereditária de um organismo que está codificada em seu DNA (ou, em alguns vírus, no RNA)" - definição de genoma, encontrada no dicionário on-line Michaelis. Com exceção de alguns vírus, o genoma de todos os organismos vivos encontrados na natureza é constituído de ADN de cadeia dupla (dupla hélice).

${ }^{4}$ Resultante da Conferência das Nações Unidas sobre Meio Ambiente e Desenvolvimento, a ECO-92.

${ }^{5}$ Artigo $2^{\circ}$.

${ }^{6}$ Artigo $3^{\circ}$, inciso $\mathrm{V}$.
} 
que correspondem a genes responsáveis em conferir a característica desejada, ou seja, o fenótipo ${ }^{7}$ do organismo. Uma vez isolado o gene de interesse, estes fragmentos de ADN são incorporados por meio de técnicas de engenharia genética no genoma do organismo-alvo, resultando em um organismo geneticamente modificado (OGM).

Com as técnicas de engenharia genética, qualquer gene de qualquer organismo pode ser isolado e transferido para o genoma de qualquer outro ser vivo, por mais divergente ou distante que esteja na escala evolucionária, resultando, assim, na obtenção dos organismos geneticamente modificados denominados transgênicos. Nesse flanco, consiste, por sua vez, o processo da transgenia, em modificar, inserir e mesclar genes de diferentes organismos.

Toda essa tecnologia, não deve interferir, por sua vez, na biodiversidade do planeta, isto é, na variedade de genes, espécies vivas e ecossistemas que integram o meio ambiente. Sob essa ótica, a Convenção da Biodiversidade utilizou o termo diversidade biológica e o definiu como "a variabilidade de organismos vivos de todas as origens e os complexos ecológicos de que fazem parte: compreendendo ainda a diversidade dentro das espécies, entre espécies e de ecossistemas".

Por seu turno, tendo em vista as crescentes interferências das inovações tecnológicas que afetam tanto os seres vivos, diretamente, quanto os seus habitats, tornou-se necessária à elaboração de uma disciplina voltada para a prevenção, minimização ou eliminação dos riscos inerentes aos processos biotecnológicos.

Esse conjunto de medidas voltado à salvaguarda da vida em suas diferentes manifestações e à preservação da integridade do ecossistema planetário denominou-se bio (= vida) segurança. Nesse diapasão, a biotecnologia (como meio e instrumento) deve submeter-se à biossegurança (condição e fim) (MILARÉ, 2005, p. 335).

\subsection{A diferença conceitual entre os termos: organismo geneticamente modifi- cado e organismo transgênico}

Ainda que os termos "organismo geneticamente modificado" e "organismo

\footnotetext{
${ }^{7}$ Aparência física e visual de um organismo, fruto da expressão dos genes desse organismo. De acordo com Wilhelm L. Johannsen: "todas as características de organismos, distinguíveis por inspeção direta da aparência ou por descrição dos métodos de medição, poderão ser caracterizadas como "fenótipo" (JUSTINA et al apud JOHANNSEN, 2012, p. 67).
} 
transgênico"8 sejam empregados, na maioria das vezes, como sinônimos, existe uma diferença semântica entre eles. Essa distinção, todavia, não é unânime entre os profissionais da área.

Entrementes, para aqueles que fazem a distinção entre esses dois termos, o conceito de organismo geneticamente modificado é mais amplo que o de organismo transgênico. Isso porque se considera transgênico o organismo cujo material genético foi alterado, por meio da tecnologia do ADN recombinante, pela introdução de genes provenientes de organismos de espécie diferente da espécie do organismo alvo.

Esses genes exógenos, que são inseridos artificial e intencionalmente no genoma do organismo alvo, são denominados transgenes. Os organismos geneticamente modificados, por sua vez, podem ser transgênicos ou não. Se o organismo alvo for modificado geneticamente por um ou mais genes provenientes de um organismo da mesma espécie, este é considerado um organismo geneticamente modificado, porém não transgênico (GUERRANTE, 2003, p. 04).

\subsection{Principais tipos de transgênicos}

A tecnologia do ADN recombinante consiste na troca de material genético, que resulta numa combinação de genes diferente do original. Desse modo, é possível realizar mutações biológicas nos organismos, visando à expressão de determinadas características de interesse.

Para que ocorra essa recombinação gênica é necessária a identificação, em primeiro lugar, dentro do genoma da planta, animal ou bactéria doadora, do gene específico que se deseja transferir. Uma vez identificado o gene de interesse, esse é isolado dos demais genes do organismo. O isolamento do(s) gene(s) de interesse é conduzido por vetores (plasmídeos ou vírus), nos quais a sequência de ADN de interesse é inserida, utilizando-se a enzima ADN ligase. Esses fragmentos de ADN (genes) são, então, incorporados no genoma do organismo alvo, para que esse comece a expressar a característica peculiar. É possível encontrar os seguintes tipos de cultivos transgênicos:

8 Vocábulo usado pela primeira vez em 1983, por Jon GORDON e Frank RUDDLE. 


\section{i) Vegetais geneticamente modificados}

Nos vegetais, a modificação genética é realizada por meio da inserção de um ou mais genes no genoma das sementes. Assim, de acordo com as características introduzidas no código genético de uma determinada semente, é possível produzir cultivos tolerantes a herbicidas, resistentes a inseticidas, tolerantes a herbicidas e resistentes a inseticidas, ao mesmo tempo, ou até mesmo, resistentes a determinado vírus.

Um dos cultivos transgênicos mais conhecidos são as sementes de soja, milho e algodão tolerantes ao glifosato, princípio ativo do herbicida fabricado pela empresa Monsanto, conhecido comercialmente como Round-up Ready (RR $)^{9}$. Sob esse mesmo enfoque, foram também produzidos, cultivos de milho tolerantes ao glufosinato de amônio, variedade, essa, conhecida como Liberty Link (LL).

Normalmente, as sementes RR são duas vezes mais tolerantes ao glifosato do que as sementes convencionais. Ademais, observa-se uma diminuição na quantidade dos produtos químicos usados nesses cultivos e consequente redução da mão de obra disponibilizada para esse fim. Em contrapartida, devido à quota tecnológica utilizada, o valor comercial das sementes transgênicas eleva-se em relação às sementes convencionais.

Outros cultivos geneticamente modificados conhecidos comercialmente são os denominados $\mathrm{Bt}$, os quais possuem em seu genoma um gene extraído de uma bactéria do solo, tradicionalmente utilizada na agricultura por suas propriedades inseticidas, chamada Bacillus thuringiensi. A inserção do gene da bactéria no código genético dessas sementes permite com que elas passem a sintetizar uma proteína que é tóxica aos insetos predadores, em especial da ordem Lepidóptera. O mesmo mecanismo utilizado na produção do milho Bt ocorre em relação ao cultivo do algodão trangênico Bollgard ${ }^{10}$.

O objetivo da referida transgenia foi a redução da quantidade de inseticidas utilizada no cultivo dessas plantações.

9 A soja denominada Roundup Ready, recebeu sua primeira autorização para comercialização em 1994, pelo Departamento de Agricultura dos EUA.

10 O algodão Bollgard, desenvolvido pela empresa Monsanto, recebeu sua primeira autorização para comercialização em 1995. Em 1996, foi aprovado no Canadá e na Austrália e, em 1997, no Japão. Em meados de 2000, esse algodão já tinha plantios comerciais na Argentina, na China, no México e na África do Sul. 
Interessante notar, com base em informações de cunho nacional e internacional, a atual conjuntura das plantações com transgênicos no mundo, tal qual se observa nos mapas abaixo colacionados:

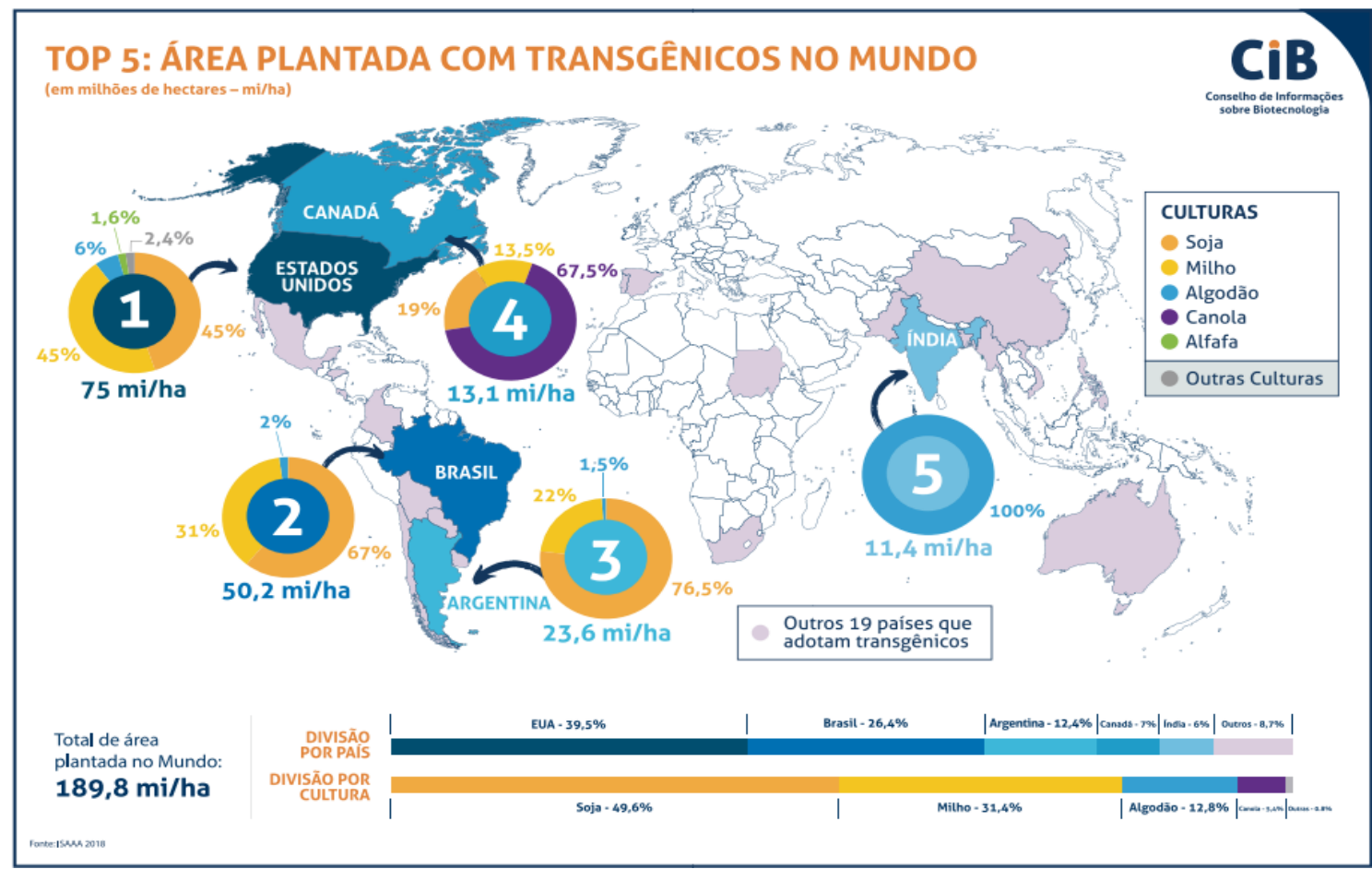

Fonte: Conselho de Informações de Biotecnologia, ISAAA (2018).

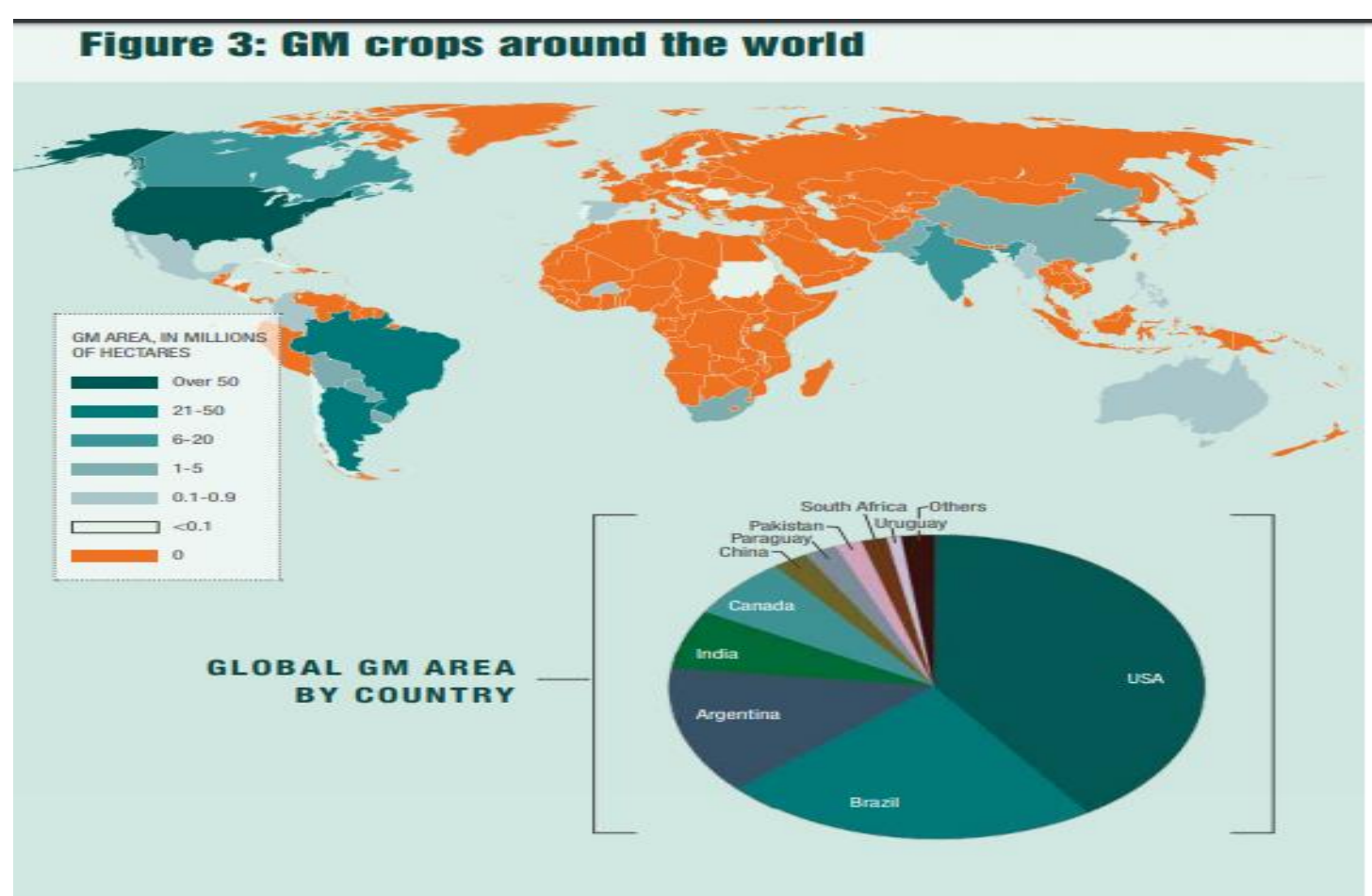

Fonte: Report 1 Where in the world are GM crops and foods? Canadian Biotechnology Action Network (CBAN), March,(2015) 


\section{ii) Bactérias transgênicas}

Há alguns anos se faz uso de bactérias geneticamente modificadas, seja para o tratamento de doenças humanas, como a diabetes, como também, para a produção alimentícia, de queijos, por exemplo. A primeira aplicação comercial de uma bactéria transgênica foi na produção de insulina humana, isso porque, até esse momento, utilizava-se para o tratamento da diabetes, insulina de origem suína, a qual era passível de provocar rejeição no organismo humano.

Outro exemplo é o caso da bactéria Escherichia coli, geneticamente modificada para produzir uma enzima chamada quimosina, empregada na formação do coalho para a produção de queijos, enzima essa, que até então, era retirada do estômago de bezerros recém-nascidos. A enzima produzida pela bactéria, além de poder ser obtida em maior quantidade, é consideravelmente mais barata que a extraída do estômago de bezerros.

\section{iii) Aplicação da ténica de transgenes no reino animal}

No que tange ao reino animal, as técnicas de engenharia genética estão sendo utilizadas com o intuito de modificar geneticamente os animais, com características de interesse, visando à produção de alimentos, de substâncias de interesse farmacêutico (como vacinas), para a produção de insulina utilizada no tratamento da diabetes, de hormônio de crescimento, e até mesmo no sentido de modificar geneticamente determinadas células de um animal, nocivo à saúde humana, de modo a tornálo inofensivo. Há, ainda, pesquisas realizadas na órbita da mutação genética de células, objetivando a produção de órgãos para o transplante humano.

\subsection{Vantagens e desvantagens dos OGMs}

\subsubsection{Possíveis benefícios}

As mutações genéticas nos vegetais podem beneficiar o meio ambiente porquanto auxiliem a redução do uso de agroquímicos e a consequente diminuição de equipamentos, maquinarias e mão de obra utilizados no controle das plantações, o que por subsequente acaba por diminuir os custos com o plantio. 
Ademais, com a diminuição de defensivos tende a haver uma menor descarga de produtos químicos no meio ambiente, e devido à respectiva redução dos labores mecânicos sobre o solo, se reduziriam também, os processos erosivos.

Com a técnica da transgenia é possível também, aumentar a qualidade nutricional dos alimentos, na medida em que se transferem genes capazes de enriquecêlos com substâncias específicas ${ }^{11}$. Além do que, visa-se a partir da engenharia genética, um aumento na produção alimentícia, fator esse, de grande consideração, tendo-se em vista o alto número da população mundial que sofre com a desnutrição.

Por meio dos organismos geneticamente modificados, ainda, pode-se produzir substâncias de valor farmacológico, como, por exemplo, vacinas e compostos utilizados no tratamento de diversas doenças.

Vale considerar, que os danos ocasionados pelos organismos geneticamente modificados encontram-se na seara da probabilidade e não da certeza. Isso devido à dificuldade de se comprovar, efetivamente, seus efeitos, tanto em detrimento do meio ambiente quanto em relação à saúde humana, tendo em vista o tempo, relativamente exíguo, de aplicação e utilização da técnica em questão.

\subsubsection{Prováveis riscos}

Os prováveis impactos negativos dos transgênicos de cunho econômico são: a monopolização do mercado pelas grandes empresas detentoras da biotecnologia transgênica e a dependência dos agricultores em relação a essas empresas, haja vista que tais empresas patenteiam o objeto dessa tecnologia, obrigando o agricultor a comprar do detentor da licença não só as sementes geneticamente modificadas, como também os agroquímicos por elas produzidos. Nessa seara, observa-se a exclusão dos pequenos agricultores que não têm condições de pagar pela respectiva cota tecnológica.

Observa-se no mais, o aumento do preço final do produto, porquanto além da utilização de uma tecnologia de ponta, os alimentos transgênicos implicam a rastreabilidade de sua cadeia produtiva e a posterior rotulagem dos produtos.

11 Vide o caso do Arroz Dourado, como ficou conhecida uma espécie japonesa de arroz, chamada Orsia sativa, na qual se transplantaram genes de uma erva nativa do Mediterrâneo e da bactéria Erwinia urederova, tornando-o mais rico em betacaroteno (vitamina A) que as espécies comuns. 
$\mathrm{Na}$ órbita ambiental, os efeitos adversos dessa biotecnologia recairiam sobre as plantações convencionais, na medida em que houvesse contaminação por meio do fluxo de genes, através da troca de pólen entre as culturas de polinização geneticamente modificadas e as culturas convencionais; tal disseminação de genes transgênicos provocaria, por sua vez, alterações imprevisíveis na cadeia ecológica.

Outra possibilidade que levaria ao desequilíbrio ambiental seria a criação de superpragas ou plantas superinvasoras, em consequência da produção de plantas geneticamente modificadas resistentes ou tolerantes a determinados produtos químicos.

Já no que tange à saúde humana, poderiam ocorrer efeitos alergênicos e de intolerância do metabolismo humano, devido ao consumo de substâncias desconhecidas, ou, conhecidas, mas presentes em maior concentração nos organismos transgênicos ${ }^{12}$.

\section{PRINCIPAIS INSTRUMENTOS LEGAIS AFETOS AOS OGMS}

Com os avanços da Biotecnologia, novas leis foram criadas e outras, já existentes, foram adaptadas às novas questões dessa ciência, não somente no âmbito nacional, como também internacional.

\subsection{Aparato Jurídico Nacional}

\subsubsection{A Constituição Federal (de 5 de outubro de 1988)}

Nossa Lei Maior normatiza em seu artigo 225, caput, o direito de todos a um meio ambiente ecologicamente equilibrado, impondo ao Poder Público e à coletividade o dever de preservá-lo e protegê-lo às presentes e futuras gerações.

12 O material genético da soja que os torna tolerantes ao herbicida é transferido para o DNA das bactérias intestinais humanas e continua funcionando. Isso significa que, muito tempo depois de pararmos de comer culturas geneticamente modificadas, suas proteínas estrangeiras podem ser produzidas dentro de nossos intestinos. A primeira safra submetida ao processo de consulta voluntária da FDA (Food \& Drug Administration) foi a do tomate FlavrSavr, a qual mostrou evidências de toxinas; das 20 ratas alimentadas com o tomate geneticamente modificado, 7 desenvolveram lesões estomacais; o tipo de lesões estomacais ligadas ao tomate poderia levar a uma perigosa hemorragia, particularmente em idosos que usam aspirina para prevenir coágulos sanguíneos. [...] Os ratos alimentados com batatas manipuladas para produzir a toxina Bt desenvolveram células anormais e danificadas, bem como o crescimento celular proliferativo na parte inferior do intestino delgado (íleo). (CHARU et al, 2011, p. 7-8). Tradução minha. 
Incumbe deste modo, ao Poder Público ${ }^{13}$ : preservar a diversidade e a integridade do patrimônio genético do país e fiscalizar as atividades dedicadas à pesquisa e manutenção de material genético; exigir, para a instalação de obra ou atividade potencialmente causadora de significativa degradação do meio ambiente, estudo prévio de impacto ambiental, a que se dará publicidade; controlar a produção, a comercialização e o emprego de técnicas, métodos e substâncias que comportem risco para a vida, a qualidade de vida e o meio ambiente.

A Carta Magna, em seu dispositivo 5ํㅡ, alíneas XXXII e XXXIII, norteia, ademais, o direito do consumidor a receber informações dos órgãos públicos acerca de qualquer atividade de interesse particular ou público, o que abrange, por sua vez, o processo de rotulagem dos organismos geneticamente modificados.

\subsubsection{Lei da Política Nacional do Meio Ambiente (Lei oㅜ 6.938, de 31 de agosto de $\underline{1981)}$}

Esta lei estabelece que qualquer atividade, que utiliza recursos ambientais, considerada potencialmente poluidora, ou capaz, sob qualquer forma, de causar degradação ambiental, dependerá de prévio licenciamento de órgão estadual competente.

Dessa forma, de acordo com a supramencionada Lei, qualquer atividade que envolva engenharia genética no Brasil, para ser autorizada, deve passar pela avaliação do órgão competente que decidirá quanto à necessidade ou não de elaboração do Estudo de Impacto Ambiental, requisito este, imprescindível à autorização da prática biotecnológica.

\subsubsection{Código de Defesa do Consumidor (Lei nº 8.078 de 11 de setembro de 1990)}

O Código de Defesa do Consumidor garante a informação do cidadão-consumidor, como consequência de suas prerrogativas constitucionais. Assim, conforme preceitua a Lei no $8.078 / 1990^{14}$, constitui direito básico do consumidor, a informação adequada e clara sobre os diferentes produtos e serviços, com especificação correta

\footnotetext{
${ }^{13}$ Artigo 225, $\S 1^{\circ}$, incisos II, IV e V, da CF.

${ }^{14}$ Artigos 4ㅇ, caput, e 6ㅇ, inciso III, do CDC.
} 
de quantidade, características, composição, qualidade e preço, bem como sobre os riscos que apresentam.

Sob esse enfoque, tem o consumidor direito às informações necessárias e adequadas a respeito dos riscos criados a sua saúde e a sua segurança, com a introdução de novos produtos no mercado de consumo ${ }^{15}$.

A esses direitos corresponde o dever do fornecedor de assegurar informações corretas, claras, precisas, ostensivas e em língua portuguesa sobre suas características, bem como acerca dos riscos que apresentem à saúde e à segurança dos consumidores, conforme preceitua o artigo 31 da referida Lei.

Dessa maneira, de acordo com imposição expressa de lei, tem o consumidor direito a ser informado com relação aos produtos, especialmente no que concerne a utilização de OGMs em sua fabricação; para que possa, então, estar apto a exercer o direito de escolha em relação ao respectivo consumo. Nessa mesma órbita, encontrar-se-ia, por seu turno, o dever do fornecedor de informar a sociedade relativamente àqueles produtos modificados artificialmente em sua composição.

\subsubsection{Direito à informação x Dever de rotulagem}

O direito à informação e o direito de escolha são direitos básicos e irrenunciáveis dos consumidores, expressos em quase todas as legislações referentes ao tema. Esta talvez seja uma das maiores polêmicas que envolvem a questão dos produtos geneticamente modificados.

Nessa monta, dispõe o artigo 40 da Lei de Biossegurança, que os alimentos e ingredientes alimentares destinados ao consumo humano ou animal que contenham ou, sejam produzidos a partir de organismo geneticamente modificado ou derivados, deverão conter informação nesse sentido em seus rótulos, conforme regulamento.

Todavia, até o momento, não fora elaborado o regulamento previsto no respectivo dispositivo, continuando, a matéria, a ser disciplinada pelo Decreto Federal $n^{\circ} 4.680$, de 24 de abril de 2003, pela Portaria $n^{\circ} 2.658$, de 22 de dezembro de 2003, do Ministério da Justiça, e pela Instrução Normativa Interministerial $n^{\circ} 1$, de $1^{\circ}$ de abril de 2004.

\footnotetext{
${ }^{15}$ Artigo 8, caput, do CDC.
} 
Dispõe, dessa forma, o Decreto Federal $n^{0} 4.680 / 2003^{16}$, que o consumidor deverá ser informado acerca dos alimentos e ingredientes alimentares destinados ao consumo humano ou animal que contenham ou, sejam produzidos a partir de OGMs, com presença acima do limite de um $1 \%$ (um por cento) do produto ${ }^{1718}$.

Com base na referida normatização, a maneira de informar o consumidor é rotulando os produtos embalados, ou seja, expondo no rótulo de sua embalagem o nome do composto transgênico inserido, ou do qual ele deriva, bem como o nome da espécie doadora do gene, além de destacar o símbolo, definido pelo Ministério da Justiça, como representativo dos organismos transgênicos $(\hat{\mathrm{T}})^{19}$.

Nesse contexto, a obrigação de colocar rótulo indicativo da presença de qualquer modificação geneticamente realizada conferiria ao cidadão-consumidor o direito à informação (preconizado em nossa Carta Magna) e, por consequência, a opção de escolha em relação ao consumo de um produto, cujas características são de efeitos desconhecidos a sua saúde. No entanto, faz-se imprescindível a consideração, neste momento, de recente decisão da Comissão de Meio Ambiente (CMA) do Senado Federal (ANEXO I), conferida em 17 de abril do ano corrente, que caminhou em sentido diametralmente oposto às salvaguardas constitucionais e infraconstitucionais.

\subsubsection{Lei de Biossegurança (Lei ํㅜ 11.105 de 24 de março de 2005)}

A Lei de Biossegurança foi precedida pela Lei ํo 8.974 de 5.1.1995 e pela Medida Provisória 2.191-9, de 23.8.2001, ambas revogadas. Esse diploma veio regulamentar os deveres constitucionais, notadamente dispostos no artigo $225 \mathrm{da}$ Carta Magna.

16 Artigo $2^{\circ}$, caput.

17 O critério para verificação do limite de 1\% é, nos termos da Instrução Normativa Interministerial no 01/04 (disponível em:<http://www.agricultura.gov.br/assuntos/insumos-agropecuarios/insumos-pecuarios/alimentacao-animal/arquivos-alimentacao-animal/legislacao/instrucao-normativa-interministerial-no-1-de-10-de-abril-de-2004.pdf/view>), a quantificação do Ácido Desoxirribonucléico (ADN) inserido ou da proteína resultante da modificação genética ou, ainda, de outras substâncias oriundas da modificação genética, por métodos de amostragem e de análise reconhecidos pelos órgãos competentes.

18 Na União Europeia, a medida é de $0.9 \%$ de organismos geneticamente modificados para rotulagem dos alimentos que o contenham. (CHARU et al, 2011, p. 9). Tradução minha.

19 "Uma vez que o rótulo dos produtos é considerado o principal veículo de informação entre o produtor e a sociedade - consumidor [...] A rotulagem é imprescindível aos alimentos. É através dos rótulos que os consumidores podem conhecer o produto que estão comprando e entender o que está sendo informado. Nesse caso, o rótulo funciona como um veículo de informação". (RIBEIRO, MARIN, 2012, p. 362). 
A biossegurança tem, assim, o escopo de preservar a saúde humana e a biodiversidade dos ecossistemas naturais, de forma a regular o uso das técnicas de engenharia genética e a assegurar a liberação no meio ambiente dos produtos dessa ciência. As atividades relativas aos OGMs abrangidas pela lei são: "construção, cultivo, manipulação, transporte, comercialização, consumo, liberação e descarte."

A referida legislação criou, ainda, os órgãos públicos destinados a dar segmento à política da biossegurança, quais sejam: o Conselho Nacional de Biossegurança, a Comissão Técnica Nacional de Biossegurança, os órgãos e entidades de registro e fiscalização e, finalmente, as Comissões Internas de Biossegurança.

\subsection{Direito Estrangeiro}

\subsubsection{União Internacional para a Proteção das Obtenções Vegetais - Upov (1961,} $\underline{1978,1991)}$

A União Internacional para a Proteção das Obtenções Vegetais (Upov) é um acordo multilateral que determina normas comuns para o reconhecimento e a proteção da propriedade das variedades de plantas obtidas por meio da biotecnologia. Estabelecida em 1961, a Upov passou dos 6 (seis) membros europeus originários para 20 (vinte) membros, no início dos anos 1990. Atualmente, os países signatários desse acordo ultrapassam 50 (cinquenta), contando inclusive com membros latinoamericanos.

A Convenção original da Upov de 1961 foi revisada em 1972, 1978 e 1991. Essa última revisão almejou de fato, equiparar o sistema Upov ao de patentes. Segundo ela, para que uma variedade transgênica seja reconhecida e patenteada, é necessária a existência de algumas características, quais sejam: distinção, estabilidade, homogeneidade, novidade.

Assim, para que uma variedade geneticamente modificada obtenha proteção, de acordo com as normas da Upov, ela deve, respectivamente: I) ser distinta de qualquer outra variedade já reconhecida; II) manter sua homogeneidade por várias gerações; III) apresentar variabilidade mínima quanto as suas características quando reproduzida sucessivamente; IV) ser inédita no âmbito comercial. 


\subsubsection{Convenção sobre a Diversidade Biológica (1992)}

"O primeiro acordo internacional a reconhecer o direito de soberania de um país em relação a seus recursos genéticos, bem como a responsabilidade deste em facilitar o acesso a esses recursos, foi a Convenção sobre a Diversidade Biológica (CDB)" (GUERRANTE, 2003, p. 75). Tal documento fora assinado durante a Conferência das Nações Unidas para o Meio Ambiente e o Desenvolvimento (ECO-92), realizada na cidade do Rio de Janeiro, em 1992, encontrando-se, atualmente, ratificado por mais de 180 países.

A referida Convenção ${ }^{20}$ ressalta a importância do acesso e da transferência de tecnologia entre os países signatários, em prol da conservação e do uso sustentável da biodiversidade. Recomenda, ainda, às partes, que regulamentem o acesso aos recursos naturais e à biotecnologia, de modo a controlar os riscos ambientais e à saúde humana, relativos ao uso e à liberação dos organismos geneticamente modificados.

Ademais, a Convenção da Diversidade Biológica, preconiza, em um de seus dispositivos, o Princípio da Precaução, elevando-o à categoria de regra de direito internacional:

Item 15. "De modo a proteger o meio ambiente, o princípio da precaução deve ser amplamente observado pelos Estados, de acordo com suas capacidades. Quando houver ameaça de danos sérios ou irreversíveis, a ausência de absoluta certeza científica não deve ser utilizada como razão para postergar medidas eficazes e economicamente viáveis para prevenir a degradação ambiental".

Os Estados soberanos devem, nesta monta, aplicar o princípio da precaução de acordo com suas respectivas capacidades, de modo que sejam evitados sérios e irreversíveis danos ambientais, mesmo que não haja certeza científica de efeitos adversos ao meio ambiente.

Dessa maneira, no que diz respeito aos OGMs, não deve ser permitido o seu uso, liberação, ou comercialização, até que sejam descartados quaisquer riscos para a saúde humana ou para o meio ambiente.

Nesse prisma, a Convenção da Diversidade Biológica recomenda às partes, como medida para a conservação in situ dos recursos naturais, que estabeleçam ou

20 Artigo 16, alínea a. 
mantenham os meios para regulamentar, administrar ou controlar os riscos associados à utilização e à liberação de OGMs, resultantes da biotecnologia que, provavelmente, provoquem impacto ambiental negativo que possa afetar a conservação e a utilização sustentável da diversidade biológica, levando também em conta os riscos para a saúde humana ${ }^{21}$.

\subsubsection{Protocolo Internacional sobre Biossegurança}

O Protocolo de Cartagena sobre Biossegurança foi firmado em Montreal, Canadá, em 28 de janeiro de 2000, pelos países signatários da Convenção da Diversidade Biológica. A adoção do Protocolo pelos Países-partes da Convenção cria uma discussão em âmbito internacional em relação às regras que deverão nortear a introdução de organismos geneticamente modificados em seus territórios ${ }^{22}$.

Dentre os preceitos desse acordo internacional, vigora o ônus da prova por parte do produtor do OGM, quanto à comprovação de que seu produto é incapaz de provocar qualquer efeito nefasto em relação ao meio ambiente ou à saúde humana, em face da aplicação do princípio da precaução. Trata-se, portanto, de um instrumento de direito internacional essencial para a regulação do comércio internacional de produtos transgênicos, e que visa a proteção do meio ambiente ecologicamente equilibrado.

\section{PROPRIEDADE INDUSTRIAL E O DIREITO À PATENTE}

No que tange ao aspecto da propriedade industrial, convém, preambularmente, mencionar o contexto no qual se constitui tal ramo do direito. Nota-se, assim, que a propriedade imaterial, relacionada na seara dos direitos imateriais, é gênero do qual são espécies, a propriedade intelectual e os direitos de personalidade. A propriedade intelectual, por sua vez, divide-se entre a propriedade industrial e os direitos autorais e conexos (TARDIN, 2015).

Embora haja menção à questão dos direitos autorais na Carta Magna, em seu

21 Artigo 8, alínea g, da CDB.

22 O protocolo encontra-se em vigor, no Brasil, desde 22 de fevereiro de 2004. 
dispositivo $5^{\circ}$, incisos $X X V I I$ a XXIX ${ }^{23}$, tal conceito não se encontra expresso no texto constitucional. Tal menção - a direitos autorais - também se faz presente na legislação internacional, consoante se observa no artigo 27 da Declaração dos Direitos Humanos $^{24}$, porém, da mesma forma, sem o conceito expresso de "propriedade intelectual".

Todavia, de forma a clarear o sentido de "propriedade intelectual", cabe transcrever a seguinte explicação:

Sob a denominação 'propriedade intelectual' agrupam-se duas grandes categorias de bens [...] $\mathrm{Na} 1^{\underline{a}}$ categoria [...] incluem-se os direitos relativos a invenções, marcas de fábrica ou de comércio, dentre outros. A $2^{\mathrm{a}}$, sob o título de 'direitos do autor', e correlatos, engloba as obras literárias, científicas, musicais, artísticas, filmes, fonogramas e demais criações semelhantes. DA COSTA, 2016, pg. 103.

Objetivando clarividente visualização do ora explanado, cabe reproduzir quadro explicativo acerca das categorias da propriedade intelectual, senão veja-se:

23 Artigo $5^{\circ}$, inciso XXVII - "aos autores pertence o direito exclusivo de utilização, publicação ou reprodução de suas obras, transmissível aos herdeiros pelo tempo que a lei fixar"; inciso XXIX - "a lei assegurará aos autores de inventos industriais privilégio temporário para sua utilização, bem como proteção às criações industriais, à propriedade das marcas, aos nomes de empresas e a outros signos distintivos, tendo em vista o interesse social e o desenvolvimento tecnológico e econômico do País."

24 "Artigo 27. 1. Todo ser humano tem o direito de participar livremente da vida cultural da comunidade, de fruir as artes e de participar do progresso científico e de seus benefícios. 2. Todo ser humano tem direito à proteção dos interesses morais e materiais decorrentes de qualquer produção científica literária ou artística da qual seja autor. (Grifo da autora)." 


\section{PROPRIEDADE INTELECTUAL}

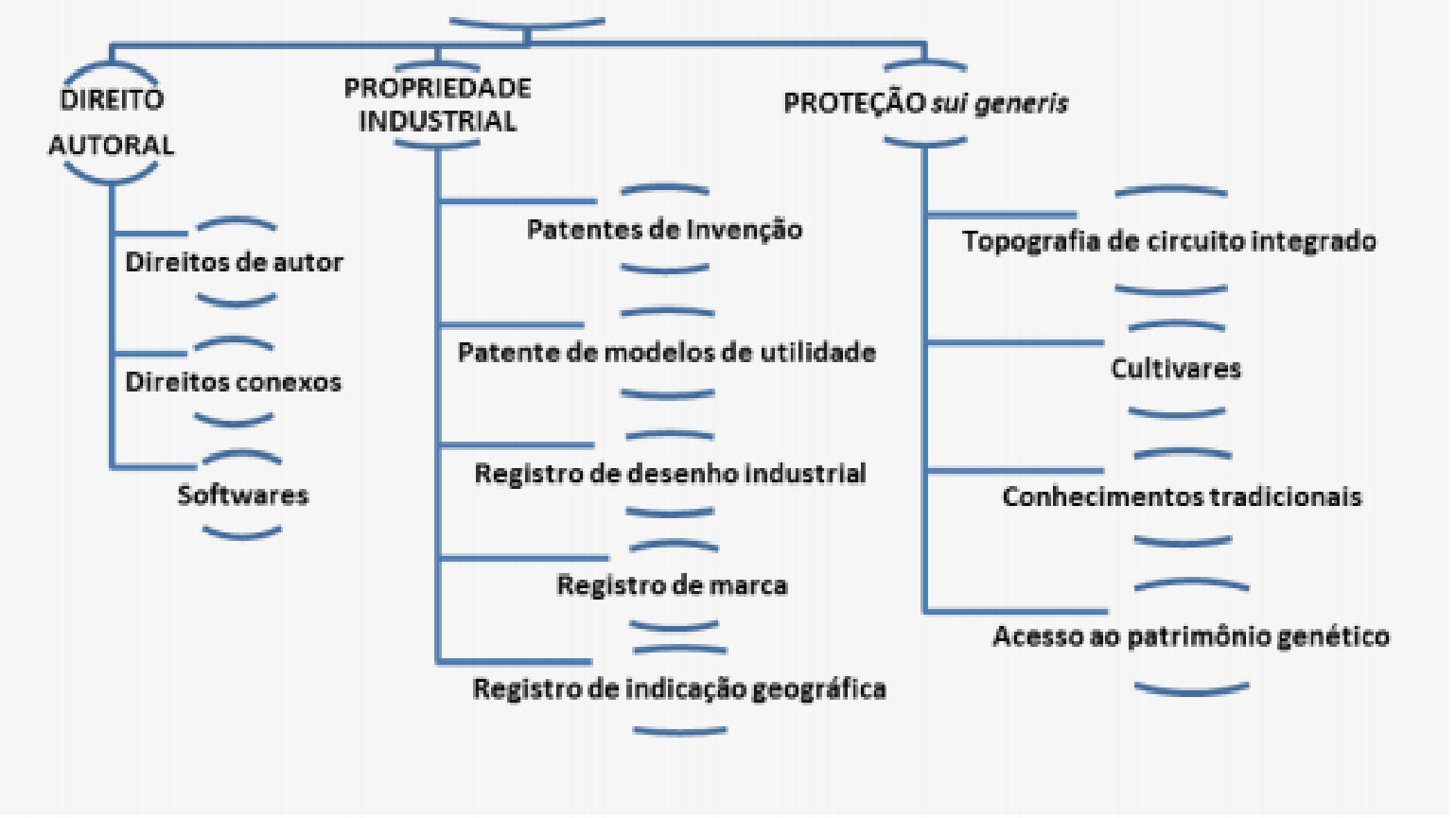

Fonte: Santos, Fontanela, figura3.

Com relação à propriedade industrial, vale anotar que: As normas reguladoras da Propriedade industrial são executadas e supervisionadas pelo INPI (Instituto Nacional da Propriedade Industrial), autarquia federal criada em 1970, encarregada do registro e concessão de marcas, patentes, desenhos industriais, transferências de tecnologia, entre outros (FALCÃO et al, 2015).

Consoante visto acima, os direitos relativos à patente encontram-se inseridos no rol dos direitos da propriedade industrial, subdividindo-se, por seu turno, em: patentes de invenção e patentes de modelos de utilidade ${ }^{25}$.

Assim, no que diz respeito propriamente ao direito de patente, vale considerar que se trata de um privilégio legal concedido pelo Estado, que confere ao titular da

25 "Tipos de patentes e prazo de validade: Patente de Invenção (PI) - Produtos ou processos que atendam aos requisitos de atividade inventiva, novidade e aplicação industrial. Sua validade é de 20 anos a partir da data do depósito. Certificado de Adição de Invenção (C) - Aperfeiçoamento ou desenvolvimento introduzido no objeto da invenção, mesmo que destituído de atividade inventiva, porém ainda dentro do mesmo conceito inventivo. O certificado será acessório à patente e com mesma data final de vigência desta. Patente de Modelo de Utilidade (MU) - Objeto de uso prático, ou parte deste, suscetível de aplicação industrial, que apresente nova forma ou disposição, envolvendo ato inventivo, que resulte em melhoria funcional no seu uso ou em sua fabricação. Sua validade é de 15 anos a partir da data do depósito". Informação disponível em: < http://www.inpi.gov.br/servicos/perguntas-frequentes-paginas-internas/perguntas-frequentes-patente>. Acesso em: 22 de junho de 2018. 
invenção o direito de impedir terceiro, sem o seu consentimento, de produzir, usar, colocar à venda, vender ou importar produto, objeto de sua patente e/ou processo ou produto obtido diretamente por processo por ele patenteado.

Interessante nesse contexto, transcrever a definição de patente, fornecida pelo próprio órgão competente pela sua análise no Brasil: Patente é um título de propriedade temporária sobre uma invenção ou modelo de utilidade, outorgado pelo Estado aos inventores ou autores ou outras pessoas físicas ou jurídicas detentoras de direitos sobre a criação. Com este direito, o inventor ou o detentor da patente tem o direito de impedir terceiros, sem o seu consentimento, de produzir, usar, colocar a venda, vender ou importar produto objeto de sua patente e/ ou processo ou produto obtido diretamente por processo por ele patenteado. Em contrapartida, o inventor se obriga a revelar detalhadamente todo o conteúdo técnico da matéria protegida pela patente. (INSTITUTO NACIONAL DA PROPRIEDADE INDUSTRIAL - INPI, Grifos da autora)

A concessão de uma patente equivale ao reconhecimento do direito de propriedade, que, do ponto de vista jurídico, é o direito real de usar, gozar, dispor da coisa, além do direito de reavê-la ${ }^{26}$. Isto significa que a patente permite ao seu titular excluir terceiros de qualquer uso do objeto patenteado, sem sua autorização.

Relacionando, todavia, o direito de patente com as questões de biotecnologia alavancadas neste trabalho, convém aludir a um relevante ponto de interseção entre as duas temáticas, que esbarra não somente na proteção do meio ambiente, mas em uma visão ampla, na ideia de sustentabilidade. Nessa toada, faz-se imprescindível a consideração do pensamento abaixo transcrito: Entretanto, no ponto que tangencia a correlação existente entre a proteção da propriedade intelectual e a preocupação referente aos efeitos que a adoção de novas tecnologias podem impor ao ideal de um desenvolvimento sustentável, não há como deixar de referir a possibilidade de aplicação do princípio da precaução durante as análises que culminam com a concessão de patente para um produto ou processo. (SILVA, WALDEMAN, 2015, p. 500).

\subsection{Requisitos para a Patenteabilidade}

No Brasil, para que uma invenção possa ser patenteada é necessário que ela preencha certos requisitos, quais sejam, novidade, atividade inventiva e aplicação

\footnotetext{
${ }^{26}$ Artigo 1.228 do Código Civil Brasileiro.
} 
industrial, conforme disposto no artigo $8^{\circ}$, da Lei de Propriedade Industrial (Lei Federal $n^{\circ}$ 9.279/ 1996).

Entretanto, reza a mesma normativa, que há exceções no tocante à patenteabilidade:

Artigo 18. Não são patenteáveis:

III- o todo ou parte dos seres vivos, exceto os micro-organismos transgênicos que atendam os três requisitos de patenteabilidade novidade, atividade inventiva e aplicação industrial - previstos no art. $8^{\circ}$ e que não sejam mera descoberta.

Parágrafo único - Para os fins desta lei, micro-organismos transgênicos são organismos, exceto o todo ou parte de plantas ou de animais, que expressem, mediante intervenção humana direta em sua composição genética, uma característica normalmente não alcançável pela espécie em condições naturais.

Vale notar que tais exceções dispostas na referida legislação brasileira encontra resguardo nas normas internacionais, estando em total consonância com o disposto no Acordo TRIPS (Agreement on Trade-Related Aspects of Intelectual Property Rigths), senão veja-se: "ARTIGO 27 Matéria Patenteável 1. Sem prejuízo do disposto nos parágrafos 2 e 3 abaixo, qualquer invenção, de produto ou de processo, em todos os setores tecnológicos, será patenteável, desde que seja nova, envolva um passo inventivo e seja passível de aplicação industrial. Sem prejuízo do disposto no parágrafo 4 do Artigo 65, no parágrafo 8 do Artigo 70 e no parágrafo 3 deste Artigo, as patentes serão disponíveis e os direitos patentários serão usufruíveis sem discriminação quanto ao local de invenção, quanto a seu setor tecnológico e quanto ao fato de os bens serem importados ou produzidos localmente. 2. Os Membros podem considerar como não patenteáveis invenções cuja exploração em seu território seja necessário evitar para proteger a ordem pública ou a moralidade, inclusive para proteger a vida ou a saúde humana, animal ou vegetal ou para evitar sérios prejuízos ao meio ambiente, desde que esta determinação não seja feita apenas por que a exploração é proibida por sua legislação. 3. Os Membros também podem considerar como não patenteáveis: a) métodos diagnósticos, terapêuticos e cirúrgicos para o tratamento de seres humanos ou de animais; b) plantas e animais, exceto microorganismos e processos essencialmente biológicos para a produção de plantas ou animais, excetuando-se os processos não-biológicos e microbiológicos. Não obstante, os Membros concederão proteção a variedades vegetais, seja por meio de patentes, 
seja por meio de um sistema sui generis eficaz, seja por uma combinação de ambos. O disposto neste subparágrafo será revisto quatro anos após a entrada em vigor do Acordo Constitutivo da OMC."27

Cabe aqui fazer referência ao fato de que, além de as hipóteses abordadas pelo acordo internacional serem apenas passíveis de exclusão pelos direitos patentários, tais hipóteses, ainda, poderiam ser objeto de alteração após quatro anos da entrada em vigor do acordo.

Dessa forma, a proteção da propriedade intelectual por patentes pressupõe que o produto ou processo seja novo, possua caráter inventivo e seja passível de inserção em um processo industrial predeterminado, ou seja, tenha aplicação industrial. Portanto, para a aplicação do sistema de proteção por patentes, estes critérios universais - invenção, novidade e interesse industrial - devem ser simultaneamente satisfeitos.

Vale mencionar, que uma patente só é válida no país onde foi concedida, sendo necessário registrá-la em todos os países nos quais interessa ter proteção.

Importante consignar que, no caso do presente estudo, a proteção por patentes, para OGMs ou organismos transgênicos, dar-se-ia na modalidade de "patente de invenção", cujo prazo de validade é de 20 anos, contados a partir da data do depósito do respectivo pedido.

\section{PATENTEAMENTO DE OGMS NO BRASIL}

A respeito da restrição mencionada alhures, relativa ao disposto no artigo 18 da Lei de Propriedade Industrial, há que se considerar as divergências doutrinárias que versam sobre o assunto.

De acordo com o entendimento da doutrina majoritária, abarcando-se aqui o posicionamento de Maria Helena Diniz, não é possível a proteção em relação a seres vivos, mesmo que modificados geneticamente, porquanto sejam esses bens de uso comum do povo, conforme disposto em nossa Lei Maior ${ }^{28}$.

Frise-se, portanto, que no diapasão desse pensamento:

\footnotetext{
27 Incorporado na legislação nacional por meio do Decreto Federal $n^{\circ} 1.355$, de 30 de dezembro de 1994.

28 Artigo 225, caput e $\S 1^{\circ}, \mathrm{V}$, da C.F.
} 
Dentre os produtos da biotecnologia, salvo os vegetais e partes de vegetais que não são patenteáveis, segundo os artigos 10, IX, e 18, III da LPI (BRASIL, 1996), todos os demais são passíveis de proteção mediante patente de invenção, desde que novos, com aplicação industrial e passo inventivo, posto que passíveis de serem caracterizados como microrganismos desde que modificados pela ação humana. (BRUCH et al. 2015, p. 20)

Desse modo, seria possível apenas a solicitação do direito de propriedade intelectual em relação às técnicas biotecnológicas, isso desde que não inseridas no conceito de técnicas de restrição do uso ${ }^{29}$.

Todavia, há outra corrente, que entende que o ordenamento jurídico brasileiro admite a patenteabilidade de micro-organismos transgênicos, desde que preenchidos os requisitos básicos para a concessão de patente, dispostos no artigo 18, inciso III e parágrafo único da Lei Federal n 9.279/ 1996. Ademais, afirma essa corrente, ser esse preceito um direito constitucional, assegurado no art. 5ำ, inciso XXIX, de nossa Carta Magna.

\subsection{Possibilidade de Proteção}

Tendo em vista a problemática quanto à patenteabilidade de seres vivos geneticamente modificados, cabe considerar que, no caso de esses seres não poderem ser acobertados pelos direitos de patente, poder-se-ia abrigá-los - saindo da esfera da propriedade industrial, mas ainda na esfera da propriedade intelectual - sob a proteção dos denominados "cultivares", também conhecidas como "patentes verdes".

A proteção de cultivares está disciplinada na Lei Federal nํ 9.456, de 1997. Tal proteção respalda em nova obtenção vegetal, distinguível de outros cultivares e espécies vegetais, por um conjunto mínimo de características morfológicas, fisiológicas, bioquímicas ou moleculares, herdadas geneticamente. Essas características, denominadas descritores, devem se mostrar homogêneas e estáveis por sucessivas gerações (BRUCH et al. apud LOUREIRO, 1999, p. 39).

Cabe trazer à baila, nesta toada, o quadro retrocolacionado, que traça uma análise comparativa entre patentes de invenção e cultivares:

${ }^{29}$ Artigo $6^{\circ}$, inciso VII e § único da Lei Federal n 11.105/2005. 


\begin{tabular}{|c|c|c|}
\hline & Patentes de invenção & Proteção de cultivares \\
\hline Responsável & INPI/MDIC & SNPC/Mapa \\
\hline \multicolumn{3}{|l|}{$\begin{array}{ll}\text { concessho da } \\
\text { proitecho }\end{array}$} \\
\hline Protecho & 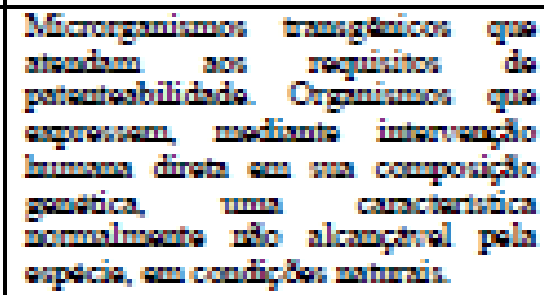 & 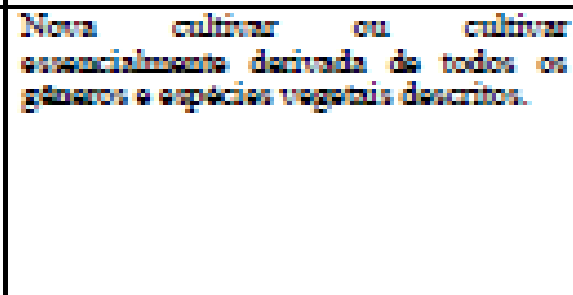 \\
\hline Friclede: & O todo ou purte de naros thos & 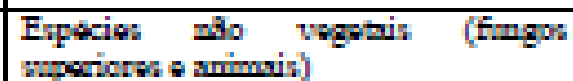 \\
\hline $\begin{array}{l}\text { Requisitos para } \\
\text { concesslo }\end{array}$ & 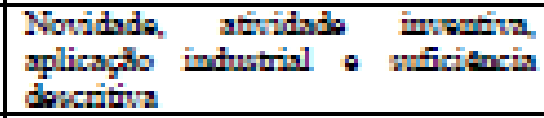 & 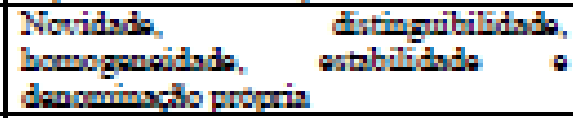 \\
\hline $\begin{array}{l}\text { Grau } \\
\text { publinugho }\end{array}$ & 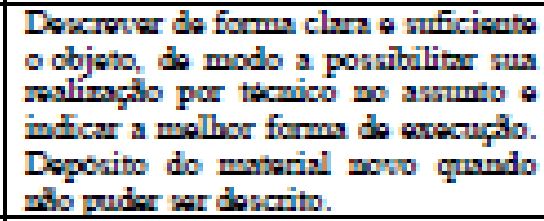 & 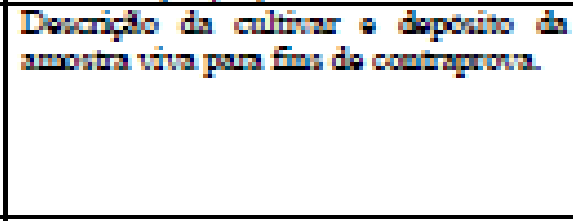 \\
\hline Reivindiraģa & 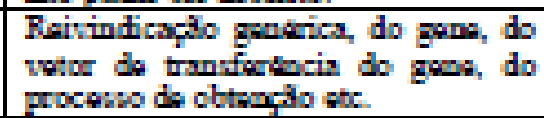 & Rakindicapho da cultivar \\
\hline Direitos & 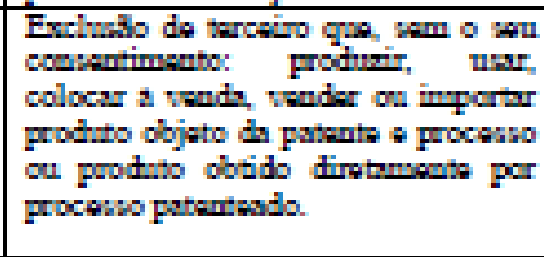 & 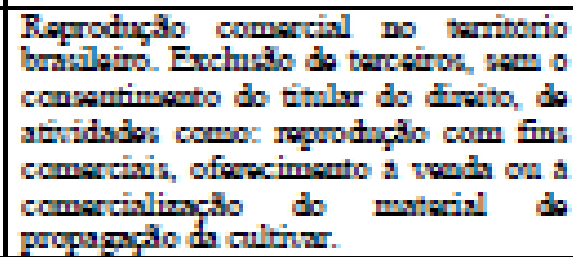 \\
\hline Priondude & Primeino a deponitar o pedido & Primairo a daporitur o patido \\
\hline \multicolumn{3}{|l|}{ Timite } \\
\hline temporisi: & 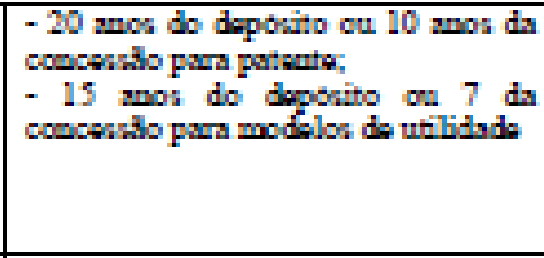 & 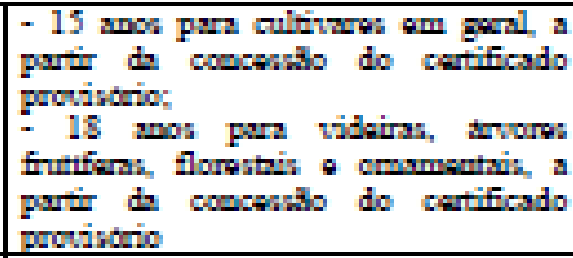 \\
\hline Temitoriais & 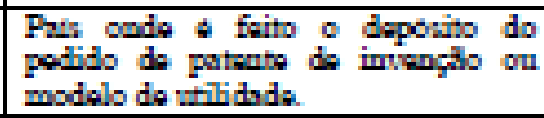 & 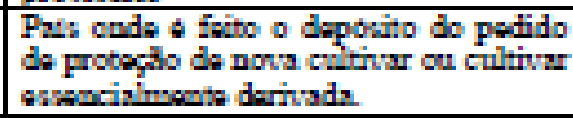 \\
\hline Legais & 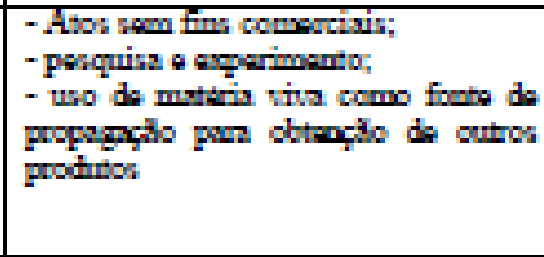 & 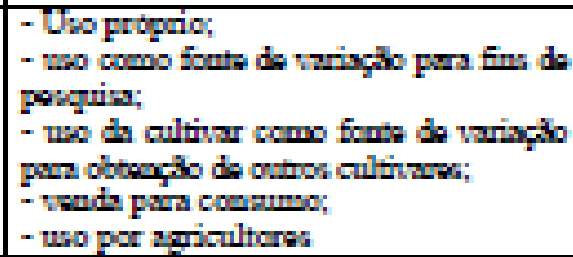 \\
\hline Compuladrios & 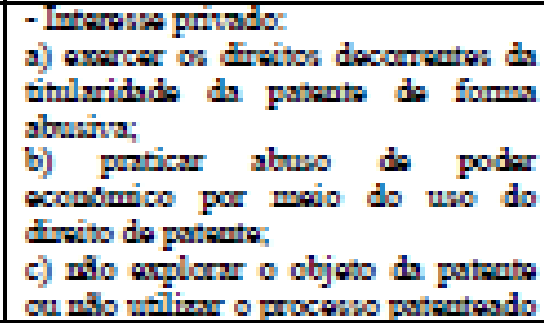 & 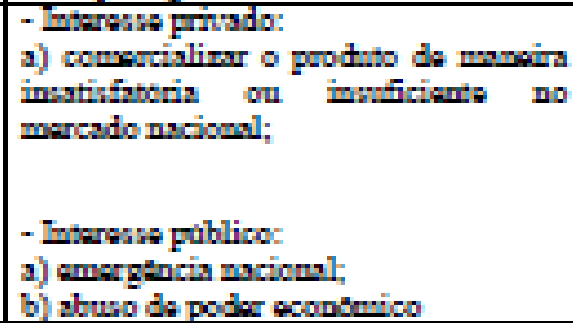 \\
\hline
\end{tabular}




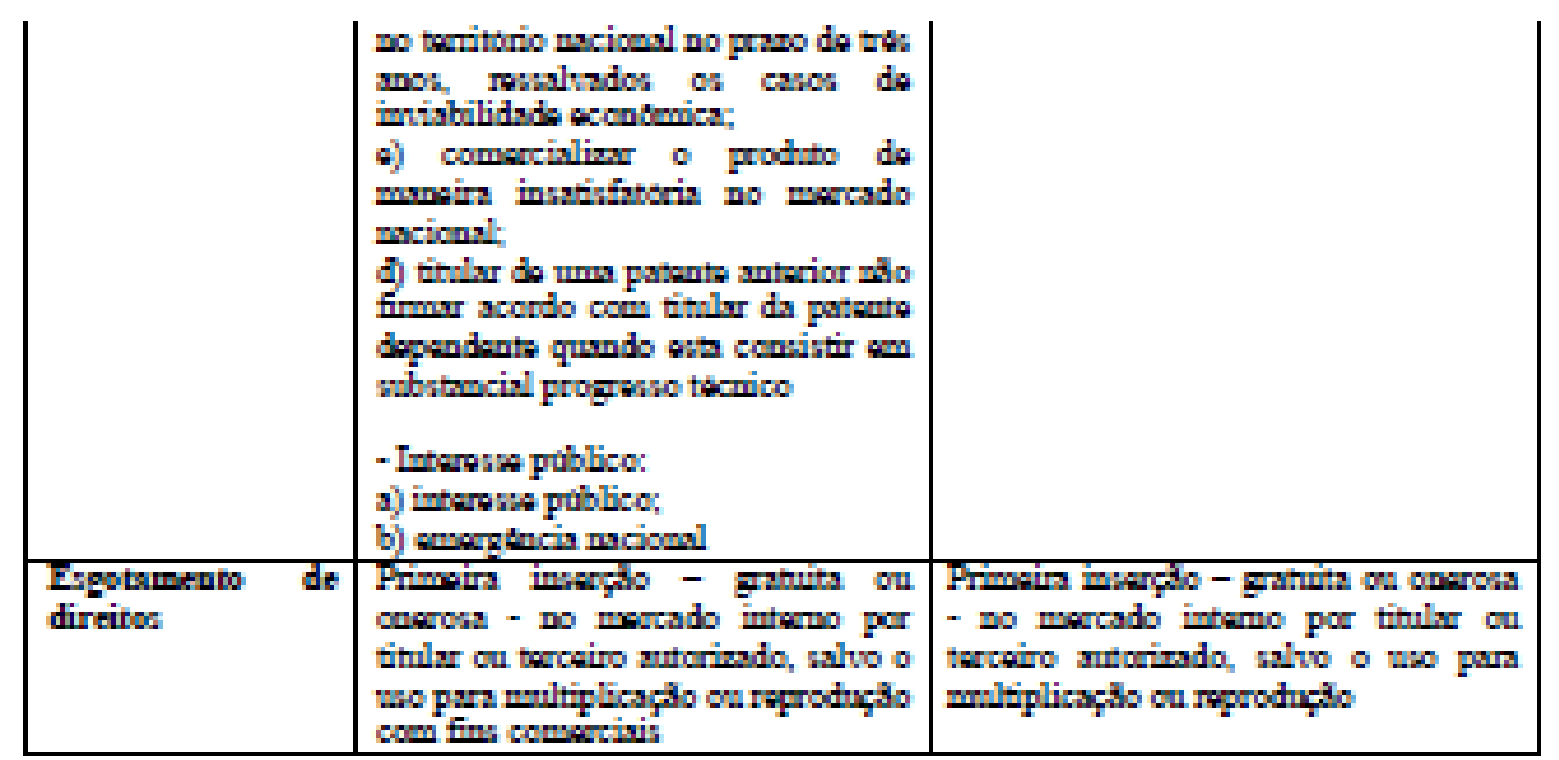

Fonte: BRUCH et al. (2015, p. 21-23)

Apenas com o intuito de esgotar a discussão e ponderar a cautela que faz vibrar os direitos imateriais aqui referendados, faz-se mister sopesar o fato de que os Estados possuidores de uma grande riqueza biológica devem ter o condão de proteger os seus recursos, de forma a impedir a biopirataria ${ }^{30}$ (conceito relativamente novo e que concerne no mal uso ou uso não autorizado dos recursos genéticos, advindos principalmente de países megadiversos, como é o caso de nosso país).

\section{CONCLUSÃO}

A guisa de uma conclusão para o presente estudo, percebe-se que tanto a biotecnologia, quanto a questão da propriedade intelectual, são questões relativamente recentes, cujos entendimentos - doutrinário, legal e jurisprudencial - encontram-se em construção e aprimoramento. Isso porque, não se veem entendimentos pavimentados com relação aos assuntos trazidos à tona na presente discussão, tampouco na seara que orbita sobre a conjunção de ambos os temas.

30 "O termo "biopirataria" foi lançado em 1993 pela ONG RAFI (hoje ETC-Group) para alertar sobre o fato que recursos biológicos e conhecimento indígena estavam sendo apanhados e patenteados por empresas multinacionais e instituições cientificas e que as comunidades que durante séculos usam e conservam estes recursos e geraram estes conhecimentos, não estão participando nos lucros. De modo geral, biopirataria significa a apropriação de recursos biogenéticos e/ou conhecimentos de comunidades tradicionais, por indivíduos ou por instituições que procuram o controle exclusivo ou monopólio sobre estes recursos e conhecimentos, sem autorização estatal ou das comunidades detentoras destes conhecimentos e sem a repartição justa e equitativa de benefícios oriundos destes acessos e apropriações. Por enquanto, ainda não existe uma definição consensual sobre o termo biopirataria". Definição disponível em: < http://biobras.org.br/portal/?p=1033> . Acesso em: 28 de junho de 2018. 
Independentemente da vertente a ser seguida com relação ao direito de patente tangente a biotecnologias, sobretudo concernente a organismos geneticamente modificados e organismos transgênicos (ou seja, se permitido o patenteamento de seres vivos modificados artificialmente; se permitido apenas o patenteamento de micro-organismos geneticamente modificados; se permitido outro tipo de proteção do direito imaterial, na esfera da propriedade intelectuak- como no caso da proteção de cultivares), o escopo precípuo de toda a regulamentação deve ser o de promover a proteção e preservação do meio ambiente e da saúde humana. Somente assim, constatar-se-á a proteção efetiva dos frutos da biotecnologia, podendo-se falar, de fato, em biossegurança e permitindo que a Magna-carta brasileira seja efetivamente cumprida, de modo a primar pelo meio ambiente ecologicamente equilibrado e salutar para as presentes e futuras gerações.

Não é crível que se possam dissociar direitos ambientais e direitos de propriedade - ainda que imateriais, razão pela qual organismos artificialmente modificados devem ser normatizados de modo tal que a sustentabilidade seja garantida, protegendo-se interesses econômicos e sociais - permitindo-se, sim, o direito à proteção de dos direitos imateriais, quiçá por meio do patenteamento de tecnologias e processos novos, porém, sem que se perca de vista, a proteção do meio em que vivemos e os possíveis riscos à preservação e saúde de todas as espécies viventes.

\section{REFERÊNCIAS}

BÁRCENA, A.; KATZ J.; MORALES C.; SCHAPER M. Los transgênicos em América Latina y el Caribe: um debate abierto. Santiago de Chile: CEPAL, 2004.

BRUCH, K. L.; VIEIRA, A. C. P.; DEWES, H. A Propriedade Industrial: dupla proteção ou proteções coexistentes sobre uma mesma planta. In: BUAINAIN, A. M.; BONACELLI, M. B.; MENDES, C. I. C. Propriedade intelectual e inovações na agricultura. Rio de Janeiro: Instituto Nacional de Ciência e Tecnologia - Políticas Públicas, Estratégias e Desenvolvimento, 2015.

CAÑELLAS, A. M. El control de producción de semillas transgénicas por medio de contratos. Revista para el análisis del Derecho, Barcelona: Indret 1, 2012.

CARVALHO, T. Patenteamento de micro-organismos transgênicos. Disponível em: https://tassiojoseleal.jusbrasil.com.br/artigos/251233310/patenteamento-de-microorganismos-transgenico>. Acesso em: 26 jun. 2018.

DA COSTA, R. A hermenêutica jurídica como instrumento de harmonização dos institutos da propriedade intelectual e o desenvolvimento sustentável. In: TEJERINA-VELÁZQUEZ, V. H., GONZALEZ; E. T.Q.; OLIVEIRA, M.C.S.A.C. Direitos humanos, propriedade intelectual e sustentabilidade. Curitiba: Juruá, 2016, p. 99-114. 
DE MORAES, A. Constituição do Brasil interpretada e legislação constitucional. 4. ed. São Paulo: Atlas, 2004.

DINIZ, M. H. O estado atual do Biodireito. 3. ed. adm. e atual. conforme o novo Código Civil (Lei n. 10.406/2002) e a Lei n. 11.105/ 2005, São Paulo: Saraiva, 2006. Grandes Eventos: Escola Superior do Ministério Público da União. Meio Ambiente - volume I. Brasília/DF: ESPMU, 2004.

DOS SANTOS, M. I. A. S.; FONTANELA, C. A proteção dos ativos intangíveis em organizações de inovação aberta. In: BARROS, C. E. C., ASSAFIM, J. M. L., PIMENTEL, L. O. Propriedade Intelectual, p. 143-158. Disponível em: http://publicadireito.com.br/artigos/?cod=27f8674dd42d4db>. Acesso em: 28 jun. 2018.

FALCÃO, P. E. F. M.; BERTELLI L. C.; SIMONASSI, F. M.; SCOLARI, F. A.; DE AZEVEDO, P.C. OGMs: organismos geneticamente modificados e o direito à patente no sistema brasileiro. Disponível em: https://jus.com.br/artigos/43097/ogms-organismos-geneticamente-modificados-e-o-direito-a-patente-no-sistema-brasileir>. Acesso em: 26 jun. 2018.

GUERRANTE, R. S. Transgênicos: uma visão estratégica. Rio de Janeiro: Interciência, 2003.

LANDRIGAN, P. J.; BENBROOK, C. GMOs, herbicides, and public health. Massachusetts: The New England Journal of Medicine, v. 373, n. 8, August 2015.

JUSTINA, L. A. D.; MEGLHIORATTI, F. A.; CALDEIRA, A. M. A. A (re)construção de conceitos biológicos na formação inicial de professores e proposição de um modelo explicativo para a relação genótipo e fenótipo. Ensaio: Pesquisa em Educação em Ciências, v. 14, n. 3, p. 1-18, 2012. Disponível em: http://hdl.handle.net/11449/134895.

MACHADO, P. A. L. Direito ambiental brasileiro: 25. ed. São Paulo: Malheiros, 2017.

MILARÉ, É. Direito do Ambiente: doutrina, jurisprudência, glossário. 4. ed. São Paulo: RT, 2005.

RIBEIRO, I. G.; MARIN, V. A. A falta de informação sobre os organismos geneticamente modificados no Brasil. Ciência \& Saúde Coletiva, v. 17, n. 2, p. 359-368, 2012.

SILVA, M. C. P. G.; WALDEMAN, R. L. O direito humano ao desenvolvimento sustentável e a proteção da propriedade intelectual: uma análise sob o enfoque da precaução. In: XXIV ENCONTRO NACIONAL DO CONPEDI - UFS, 24., 2015. Anais... Florianópolis, 2015, p. 486-506.

TARDIN, B. Diferença entre os direitos de propriedade industrial e os direitos autorais e conexos. Disponível em: https://jus.com.br/artigos/44687/diferenca-entre-os-direitos-depropriedade-industrial-e-os-direitos-autorais-e-conexos. Acesso em: 27 jun. 2018.

VARELLA, M. D.; PLATIAU, A. F. B. Princípio da precaução. Belo Horizonte: ESMPU - Escola Superior do Ministério Público da União, 2004.

VERMA, C.; NANDA S.; SINGH, R.K.; SINGH, R.B.; MISHRA, S. A review on impacts of genetically modified food on human health. The Open Nutraceuticals Journal, n. 4, p. 3-11, 2011. 
YUNTA, E. R. Temas éticos en investigación internacional com alimentos transgénicos.

Acta Bioethica, v. 19, n. 2, p. 209-218, 2013. 
ANEXO I -

\section{Comissão do Senado aprova fim da rotu- lagem de alimentos transgênicos $A$}

20 de Abril de 2018 Hara Flaeschen sob supervisão de Vilma Reis

A Comissão de Meio Ambiente (CMA) do Senado Federal votou, na última terça-feira (17), favoravelmente ao Projeto de Lei que desobriga empresas a denunciarem a presença de transgênicos em seus produtos alimentícios. A proposta, que tramita no Senado desde 2015, visa retirar o triângulo amarelo com a letra "T", símbolo da existência de organismos geneticamente modificados (OGMs).

Segundo relator da CMA, o senador Cidinho Santos (PR-MT), não haveria danos para a população: "A despeito dos alimentos transgênicos serem uma realidade há mais de 15 anos no mundo, ainda não há registros de que sua ingestão cause danos diretos à saúde humana. Não existe um registro sequer"(Agência Senado). $\mathrm{Ci}$ dinho propõe que só alimentos com taxas de concentração de OGMs acima de 1\% mantenham a rotulagem de alerta.

Desde que o debate iniciou-se a Abrasco tem se manifestado. Em carta enviada aos parlamentares, a associação pediu que "os senhores senadores não deixem que esse atentado à saúde dos brasileiros se consuma”. A Abrasco também assinou um documento, em conjunto com outras organizações da sociedade civil, justificando que o projeto não deve ser aprovado pois :

- Reverte a decisão do Tribunal Regional Federal da Primeira Região que em agosto de 2012 decidiu que independentemente do percentual e de qualquer outra condicionante, deve-se assegurar que todo e qualquer produto geneticamente modificado ou contendo ingrediente geneticamente modificado seja devidamente informado (Apelação nº 2001.34.00.022280-6);

- Prejudica o controle adequado dos transgênicos, já que a rotulagem de transgênicos é medida de saúde pública relevante para permitir o monitoramento pós-introdução no mercado e pesquisas sobre os impactos na saúde;

- Viola o direito dos agricultores e das empresas alimentícias que optam por produzir alimentos isentos de ingredientes transgênicos. $E$ pode impactar fortemente as exportações, na medida em que a rejeição às espécies transgênicas em vários países que importam alimentos do Brasil é grande; 
- Contraria o compromisso assumido pelo Congresso Nacional em 2005, quando aprovou a nova Lei de Biossegurança, Lei 11.105, e reiterou no artigo 40 que: "Os alimentos e ingredientes alimentares destinados ao consumo humano ou animal que contenham ou sejam produzidos a partir de OGM ou derivados deverão conter informação nesse sentido em seus rótulos, conforme regulamento."

A carta conjunta apresenta ainda muitas outras razões, e pode ser lida aqui.

O Instituto de Defesa do Consumidor (Idec) posiciona-se veementemente contra o Projeto de Lei e elaborou a campanha pela continuação da rotulagem de transgênicos no Brasil. O Idec também produziu um breve panorama do uso de transgênicos no país, a fim de conscientizar a população sobre a gravidade da mudança:

Atualmente, o Brasil é o segundo maior produtor de Transgênicos do planeta, tendo como transgênicos cerca de $94,2 \%$ da soja e $84,6 \%$ do milho cultivados em seu território (onte).

A introdução de transgênicos na natureza ameaça seriamente a nossa biodiversidade, já que este modelo privilegia a monocultura, que carrega impactos como a pouca variedade de fauna e flora e a consequente degradação do solo, dentre diversos outros problemas. Além disso, as alterações no patrimônio genético das nossas plantas e sementes estão diretamente ligadas ao aumento do uso de agrotóxicos: muitas sementes são modificadas para que sejam resistentes a estes produtos químicos, que passam a ser usados indiscriminadamente nas plantações.

Dessa forma, a agricultura e os agricultores tornam-se reféns de poucas empresas que detêm a tecnologia, e a saúde de agricultores e consumidores é colocada em risco. Assim, enquanto produtores de orgânicos precisam passar por um rigoroso processo de fiscalização para provarem a qualidade dos alimentos, produtores convencionais têm seus produtos circulando com facilidade no mercado.

Além da Comissão de Meio Ambiente, o Projeto de Lei já havia sido aprovado pela Comissão de Agricultura e Reforma Agrária (CRA) e reprovado pelas Comissões de Ciência, Tecnologia, Inovação, Comunicação e Informática (CCT) e Assuntos Sociais (CAS). Agora, a análise do projeto está em análise pela Comissão de Transparência, Fiscalização e Controle (CTFC). 


\section{ANEXO II}

FONTE: INPI <https://gru.inpi.gov.br/pePI/jsp/patentes/PatenteSearchBasico.jsp>. Acesso: 28 de junho de 2018.

\section{A) Depósito de pedido nacional de patente de feijão transgênico}

Depósito de pedido nacional de Patente

(21) No do Pedido: BR 1020130326771 A2

(22) Data do Depósito: 18/12/2013

(43) Data da Publicação: 23/09/2014

(47) Data da Concessão: -

(30) Prioridade Unionista:

\begin{tabular}{c|c|c|}
\hline (33) País: & (31) Número: & (32) Data: \\
\hline ESTADOS Unidos & $61 / 739,349$ & $19 / 12 / 2012$
\end{tabular}

(51) Classificação IPC: C12N 15/82; A01H 5/00; C12N 5/04

TRANSFORMAÇÃO MELHORADA DO FEIJÃO DE SOJA PARA A PRODUÇÃO DO EVENTO TRANSGÊNICO EFICIENTE E DE ALTO-RENDIMENTO

TRANSFORMAÇÃO MELHORADA DO FEIJÃO DE SOJA PARA A PRODUÇÃO DO EVENTO TRANSGÉNICO EFICIENTE E DE ALTO-RENDIMENTO. A invenção refere-se a um método para a transformação da linha germinativa mediada por

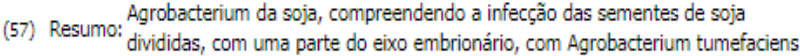
contendo um transgene. 0 método pode ainda compreender a regeneração dos explantes produzidos a partir da transformação das sementes de soja divididas compreendendo uma parte do eixo embrionário ín vitro no meio de seleção.

(71) Nome do Depositante: DOW AGROSCIENCES LLC (US) DAYAKAR PAREDDY / SIVARAMA REDDY CHENNAREDDY / TATYANA

(72) Nome do Inventor: MINNICKS / OLGA KARPOA / DAVID GRIFFIN / JAYAKUMAR P. SAMUEL / KELLEY A. SMITH / RODRIGO SARRIA-MILLAN / TEJINDER KUMAR MALL

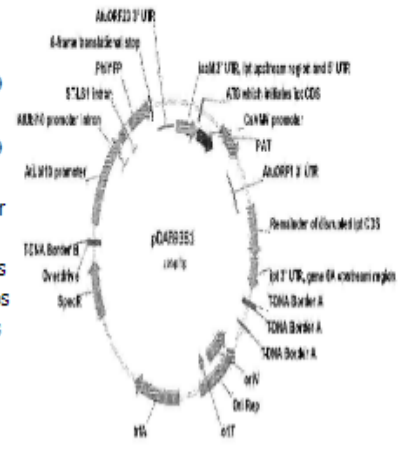

(74) Nome do Procurador: DANNEMANN, SIEMSEN, BIGLER \& IPANEMA MOREIRA - API 192

\section{B) Número de pedidos nacionais de patentes relacionadas a organismos transgênicos}

\begin{tabular}{|c|c|c|c|}
\hline $\begin{array}{l}\text { Pesquisa por: } \\
\text { Todas as palavray. TRA } \\
\text { Foram encontrafos } 37\end{array}$ & NGGÊNICOS $n$ & 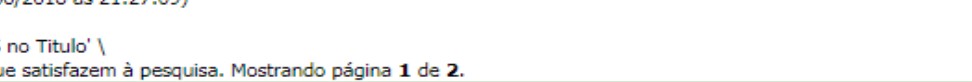 & \\
\hline Pedido & Depósito & Título & IPC \\
\hline BR 1120150264999 & $17 / 04 / 2014$ & $\begin{array}{l}4 \text { MÉTOODO PARA CARACTERIZAR UMA SEQUÊNCIA-ALVO NO GENOMA DE UMA PLANTA, } \\
\text { MÉTODO PARA ANÁLISE DE ALTO RENDIMENTO DE EVENTOS TRANSGÊNICOS. }\end{array}$ & $\mathrm{C} 12 \mathrm{Q}_{1 / 68}$ \\
\hline BR 1120150234143 & $15 / 03 / 2014 /$ & 4 ANIMAIS TRANSGÊNICOS COM CARACTERÍSTICAS PERSONALIZÁVEIS & A01K $67 / 027$ \\
\hline BR 1120140200890 & $15 / 02 / 2013$ & 3 ANIMAIS TRANSGÊNICOS COM CARACTERÍSTICAS QUE PODEM SER CUSTOMIZADAS & A01K 67/027 \\
\hline BR 1120140131210 & $30 / 11 / 2012$ & $\begin{array}{l}\text { ANIMAIS TRANSGÊNICOS FÉRTEIS ÚTEIS PARA PRODUÇÃO DE ANTIBIÓTICOS PORTANDO } \\
\text { REGIÕES VARIÁVEIS HUMANAS }\end{array}$ & C12N 15/85 \\
\hline BR 1120140099413 & $26 / 10 / 2012$ & $\begin{array}{l}\text { CAMUNDONGOS TRANSGÊNICOS EXPRESSANDO MOLÉCULAS DO COMPLEXO DE } \\
\text { HISTOCOMPATIBILIDADE PRINCIPAL (MHC) QUIMÉRICO CLASSE II }\end{array}$ & A01K $67 / 027$ \\
\hline BR 1120120202570 & $11 / 02 / 20111$ & 1 MÉTODOS E APARELHOS PARA PRODUZIR ARTIODÁTILOS TRANSGÊNICOS & A01K 67/027 \\
\hline BR 1120120122541 & $23 / 11 / 2010$ & $\begin{array}{l}\text { CONSTRUTO DE EXPRESSÃO ISOLADO, ANIMAL TRANSGÊNICO, E, MÉTODOS PARA } \\
\text { PRODUZIR UMA FÊMEA DE FINALIZAÇ̃̃O DE LINHAGEM, PARA PROPAGAR ANIMAIS } \\
\text { TRANSGÊNICOS COM CONSTRUTO DE ESTERILIDADE MATERNA, E PARA GERAR UMA } \\
\text { GERAÇÃO ESTÉRIL DE ANIMAIS }\end{array}$ & $\mathrm{C} 12 \mathrm{~N} \mathrm{15/63}$ \\
\hline BR 1120120004484 & $06 / 07 / 2010$ & $\begin{array}{l}\text { CASSETE DE EXPRESSÃO PARA A REGULAÇ̃̃o DA EXPRESSÃO SEMENTE-ESPECÍFICA DE UM } \\
\text { POLINUCLEOTÍDEO DE INTERESSE, VETOR, CÉLULA HOSPEDEIRA, TECIDO DE PLANTA, } \\
\text { ÓRGÃO DE PLANTA, PLANTA OU SEMENTE TRANSGÊNICOS, METODO PARA EXPRESSAR UM } \\
\text { POLINUCLEOTÍDEO DE INTERESSE EM UMA CÉLULA HOSPEDEIRA, MÉTODOS PARA } \\
\text { PRODUZIR UM TECIDO VEGETAL, ÓRGÃOO DE PLANTA, PLANTA, OU SEMENTE TRANSGÊNICOS } \\
\text { E USO DO CASSETE DE EXPRESSÃ̃o }\end{array}$ & $\mathrm{C} 12 \mathrm{~N} 15 / 82$ \\
\hline PI 0922479-3 & $30 / 11 / 2009$ & $\begin{array}{l}\text { ANIMAIS TRANSGÊNICOS NÃO HUMANOS QUE EXPRESSAM OS ANTICORPOS HUMANIZADOS } \\
\text { E USO DELES }\end{array}$ & $\mathrm{C} 12 \mathrm{~N} \mathrm{15/85}$ \\
\hline PI 0908831-8 & $16 / 02 / 2009$ & $\begin{array}{l}\text { MÉTODOS PARA IDENTIFICAR O EVENTO E6611.32.1.38 EM AMOSTRA BIOLÓGICA, PARA } \\
\text { DETECTAR A PRESENÇA DO EVENTO E6611.32.1.38 OU A PROGÊNIE DESTE EM UMA } \\
\text { AMOSTRA BIOLÓGICA, PARA DETECTAR A PRESENÇA DE DNA CORRESPONDENTE AO EVENTO } \\
9 \text { E6611.32.1.38 EM UMA AMOSTRA, PARA SELECIONAR SEMENTES COM A PRESENÇA DO } \\
\text { EVENTO E6611.32.1.38, MOLÉCULA DE DNA ISOLADA, SEQUÊNCIA DE NUCLEOTÍDEOS DE } \\
\text { PRIMER DE DNA, PAR DE SEQUÊNCIAS DE DNA ISOLADAS, PLANTA, CÉLULA, TECIDO, } \\
\text { SEMENTE TRANSGÊNICOS OU PARTES DESTES CONTENDO DNA. }\end{array}$ & $\mathrm{C} 12 \mathrm{~N} 15 / 82$ \\
\hline $\begin{array}{l}\text { PI } 0906672-1 \\
\text { PI } 0822557-5\end{array}$ & $05 / 01 / 2009$ & $\begin{array}{l}9 \text { MICROORGANISMOS TRANSGÊNICOS FOTOSSINTÉTICOS E FOTOBIORREATOR } \\
8 \text { COELHOS TRANSGÊNICOS PRODUTORES DE FATOR VII HUMANO }\end{array}$ & $\begin{array}{l}\text { C12M } 1 / 00 \\
\text { A01K } 67 / 027\end{array}$ \\
\hline PI 0715604-9 & $21 / 08 / 2007$ & $\begin{array}{l}\text { 7PROCESSO DE GERAÇ̃̃O DE CAMUNDONGOS TRANSGÊNICOS COM EXPRESSÃO REDUZIDA DA } \\
\text { PROTEÍNA TRANSPORTADORA DE ACETILCOLINA VESICULAR (VAChT) }\end{array}$ & $\mathbf{A}_{\mathrm{A01K}} 67 / 033$ \\
\hline PI $0710407-3$ & $03 / 05 / 2007$ & $\begin{array}{l}\text { POLIPTÍDEOS, PEIXES-ZEBRA TRANSGÊNICOS, MODELOS DE SISTEMAS, MÉTODOS DE } \\
\text { IDENTIFICACĈ̃OO DE COMPOSTOS, DE IDENTIFICAÇÃOO DE AGENTES, MÉTODOS DE } \\
\text { TRATAMENTO DE DISFUNÇÕES RELATIVAS A APOPTOSE, MÉTODO DE IDENTIFICAÇÃO DE } \\
\text { AGENTES DE PREVENÇ̃O OU REDUÇÃO DA APOPTOSE, COMPOSIÇÃO DE AUMENTO DA } \\
\text { APOPTOSE, COMPOSIÇÕES DE REDUÇÃO OU PREVENÇÃO DE APOPTOSE, COMPOSIÇÃO DE } \\
\text { APOPTOSE, MÉTODO DE DETECÇÃOO, KITS E ARTIGO INDUSTRIALIZADO }\end{array}$ & $\operatorname{cotK} 14 / 46$ \\
\hline
\end{tabular}




\section{C) Única patente nacional de transgênicos concedida}

" Consultar por: Base Patentes | Finalizar Sessão

RESULTADO DA PESQUISA (26/06/2018 às 21:41:05)

Pesquisa por:

Patente Concedida; Título: 'TRANSGenicos' ।

Foram encontrados 1 processos que satisfazem à pesquisa. Mostrando página 1 de 1 .

$\begin{array}{ccc}\text { Pedido } & \text { Depósito } & \text { Título } \\ \text { PI } 0715604-9 & 21 / 08 / 2007 & \text { PROCESSO DE GERAÇÃO DE CAMUNDONGOS TRANSGÊNICOS COM EXPRESSÃO REDUZIDA DA } \\ \text { PROTEÍNA TRANSPORTADORA DE ACETILCOLINA VESICULAR (VAChT) }\end{array}$
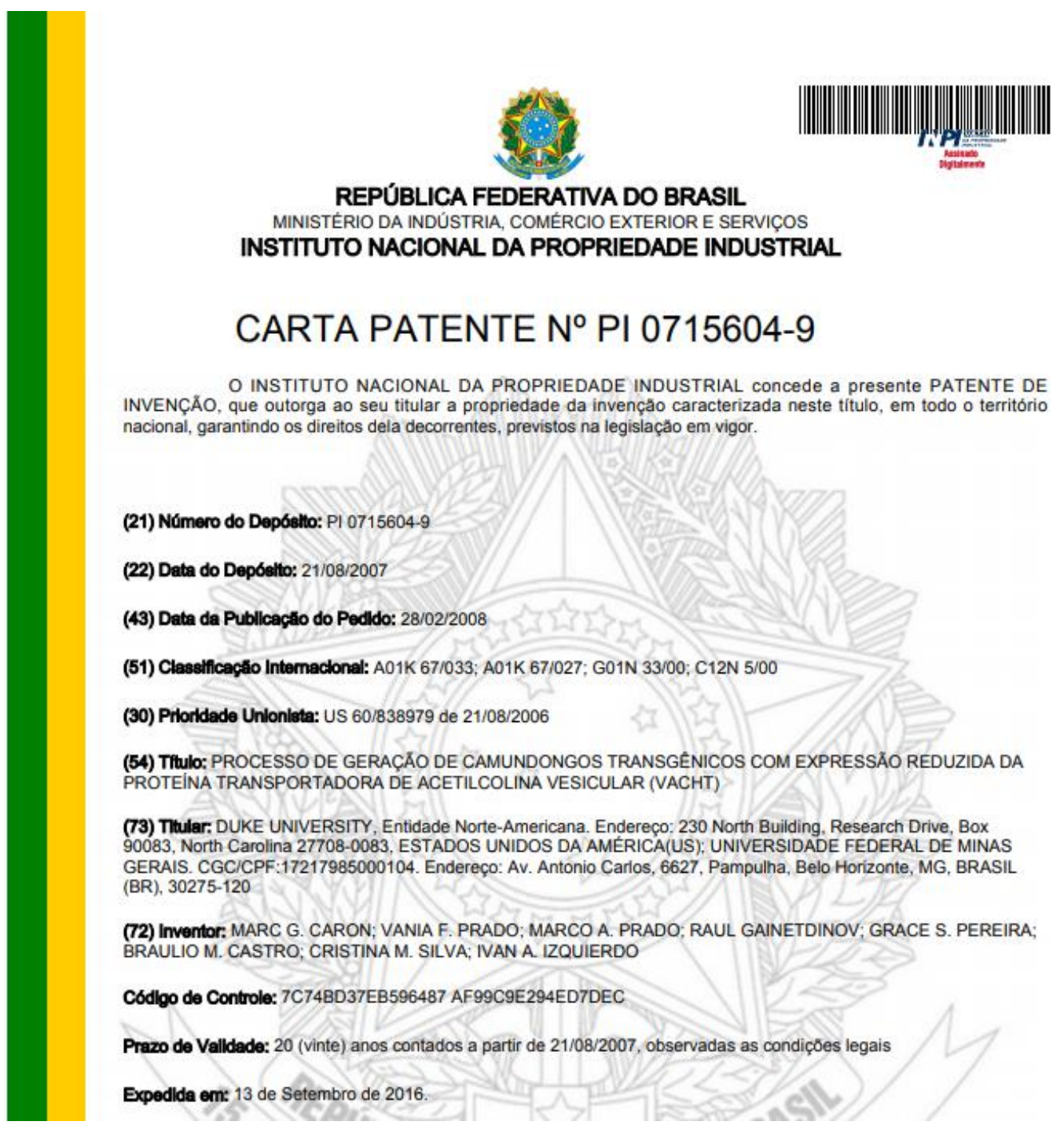

\section{CARTA PATENTE N PI 0715604-9}

O INSTITUTO NACIONAL DA PROPRIEDADE INDUSTRIAL concede a presente PATENTE DE INVENÇÃO, que outorga ao seu titular a propriedade da invençăo caracterizada neste titulo, em todo o território nacional, garantindo os direitos dela decorrentes, previstos na legislaçăo em vigor.

(21) Número do Dep6etto: Pl $0715604-9$

(22) Data do Dep6elto: 21/08/2007

(43) Data da Publlcaçấ do Pedido: 28/02/2008

(51) Clasefficagâo Internaclonal: A01K 67/033; A01K 67/027; G01N 33/00; C12N 5/00

(30) Prioridade Unlonlata: US 60/838979 de 21/08/2006

(54) Titulo: PROCESSO DE GERAÇÃO DE CAMUNDONGOS TRANSGÉNICOS COM EXPRESSÃO REDUZIDA DA PROTEINA TRANSPORTADORA DE ACETILCOLINA VESICULAR (VACHT)

(73) Thular: DUKE UNIVERSITY, Entidade Norte-Americana. Endereço: 230 North Building, Research Drive, Box 90083, North Carolina 27708-0083, ESTADOS UNIDOS DA AMÉRICA(US); UNIVERSIDADE FEDERAL DE MINAS GERAIS. CGCICPF:17217985000104. Endereço: Av. Antonio Carlos, 6627, Pampulha, Belo Horizonte, MG, BRASIL (BR), 30275-120

(72) Inventor: MARC G. CARON; VANIA F. PRADO; MARCO A. PRADO; RAUL GAINETDINOV; GRACE S. PEREIRA; BRAULIO M. CASTRO; CRISTINA M. SILVA; IVAN A. IZQUIERDO

Codlgo de Controle: 7C74BD37EB596487 AF99C9E294ED7DEC

Prazo de Valldade: 20 (vinte) anos contados a partir de 21/08/2007, observadas as condiçס̋es legais

Expedida em: 13 de Setembro de 2016. 